\author{
Magdalena Alicja Kasper \\ Uniwersytet Jagielloński \\ magdalena.kasper@interia.eu
}

\title{
Gospodarcze skutki dążeń niepodległościowych w Katalonii w latach 2010-2020
}

\begin{abstract}
Abstrakt
Katalonia uznawana jest przez ekonomistów za jeden z najlepiej rozwijających się regionów nie tylko Hiszpanii, ale także Europy. Dzięki bardzo dobrze rozwiniętej gospodarce wzbudza zainteresowanie inwestorów zagranicznych (niemieckich, francuskich, szwajcarskich), którzy decydują się nawiązywać kontakty biznesowe i umieszczać swój kapitał właśnie w tej części Hiszpanii, przyczyniając się tym samym do jej wzrostu gospodarczego. Ta sama świadomość ekonomiczna Katalończyków (obok świadomości historycznej i tożsamości narodowej) stanowi jedną z przyczyn niegasnących dążeń niepodległościowych. Wydarzeniami, które w ostatniej dekadzie znacząco wpłynęły nie tylko na stabilność polityczną, ale także na sytuację ekonomiczną Katalonii, były dwa „referenda” zorganizowane w roku 2014 oraz 2017. Ich korelację z wybranymi podsektorami katalońskiej gospodarki prezentują m.in. takie wskaźniki makroekonomiczne jak BIZ czy IPI, których wartości (szczególnie po roku 2017) drastycznie spadły. Decyzje Trybunału Konstytucyjnego o nielegalnym charakterze działań władz w Katalonii, wyroki sądu nakładające kary więzienia na polityków za rebelie i sprzeniewierzenie środków publicznych, a w końcu chaos informacyjny, wywołały niepewność partnerów biznesowych, doprowadzając w konsekwencji do pogorszenia się sytuacji gospodarczej w ostatnich latach w tym regionie Hiszpanii. W niniejszym artykule analizie ekonomicznej poddane zostały lata 2010-2020, w ciągu których największym negatywnym wydarzeniem było „referendum niepodległościowe” w Katalonii w roku 2017.
\end{abstract}


Słowa kluczowe: Katalonia, dążenia niepodległościowe, stabilność polityczna, sytuacja ekonomiczna, gospodarka

\begin{abstract}
Economic Effects of the Independence Aspirations of Catalonia in 2010-2020

Catalonia is treated by economists as one of the best developing regions not only in Spain, but also in Europe. Thanks to a very well-developed economy, it arouses the interest of foreign investors (German, French, Swiss) who decide to establish business contacts and place their capital in this part of Spain, contributing to its economic growth. The same economic awareness of the Catalans (along with the historical awareness and national identity) is at the basis of unwavering aspirations for independence. The events that significantly influenced not only political stability in the last decade, but also the economic situation of Catalonia were two referenda organized in 2014 and 2017. Their correlation with selected sub-sectors of the Catalan economy is shown e.g by macroeconomic indicators such as FDI or IPI, the values of which (especially after 2017) dropped drastically. The decisions of the Constitutional Court on the illegal nature of actions taken by the authorities in Catalonia, court sentences imposing imprisonment on politicians for rebellions and misappropriation of public funds, and finally information chaos, caused uncertainty among business partners, resulting in the deterioration of the economic situation in recent years in this region of Spain. In this article, the economic analysis covers the years 2010-2020, during which the biggest negative event was the "independence referendum" in 2017.
\end{abstract}

Keywords: Catalonia, independence aspirations, political stability, economic situation, economy

\title{
Wprowadzenie
}

Kwestie dotyczące stabilizacji politycznej regionu, państwa czy grupy państw niezaprzeczalnie wpływają na stan gospodarki. Wioletta Husar w artykule „¿Cataluña como un estado? Rozważania wokół secesji Katalonii” wskazuje najważniejsze jej zdaniem czynniki mające bezpośredni wpływ na stabilizację (lub destabilizację) polityczną: decentralizacja, regionalizmy, migracje i dążenia separatystyczne (Husar, 2016: 213). Każdy z tych czynników wynika z prowadzonej polityki, aktualnych nastrojów społecznych, uwarunkowań historycznych czy poczucia tożsamości. W ciągu ostatnich lat można zauważyć, że 
narody, które nie posiadają własnego państwa, coraz częściej wysuwają nie tylko roszczenia dotyczące poszerzenia własnej autonomii, ale nierzadko postulują utworzenie nowego organizmu państwowego bądź tworzą państwo tzw. ,samozwańcze”, a przykładem może być choćby Cypr Północny (Śmigasiewicz, 2014: 184). Co ciekawe, w związku z podobnymi roszczeniami pojawiła się terminologia pozwalająca nazywać takie twory quasi-państwem czy „państwem w państwie”. Jak pisze Marcin Kosienkowski (2008), pojęcia te stosowane są przede wszystkim w kontekście państwa nieuznanego, samozwańczego, separatystycznego, z wybranych przyczyn (kulturowych czy ekonomicznych) państwa de facto niepodległego, które nie tylko posiada wybrane cechy państwa ujęte np. w definicji Maksa Webera, ale ponadto cieszy się poparciem swojej ludności i ma przede wszystkim na tyle dobrze rozwiniętą organizację instytucjonalną, że umożliwia ona pobór podatków, świadczenie usług własnej ludności oraz prowadzenie działalności biznesowej z partnerami międzynarodowymi (Spears, 2004: 16, 22-24). Przykładem państwa wielonarodowościowego, które mierzy się z tendencjami odśrodkowymi, jest Hiszpania, w której spośród 17 communidades autónomas najsilniejsze poczucie odrębności regionalnej reprezentują Katalonia oraz Kraj Basków. Regiony te posiadają nie tylko odrębne instytucje polityczne (w Katalonii Generalitat de Catalunya, w Kraju Basków Eusko Jaurlaritza), lecz także znaczny stopień jedności i solidarności narodowej ukształtowanej przez historię, kulturę i własny język, oraz dobrze rozwiniętą gospodarkę.

Celem artykułu jest zaprezentowanie struktury gospodarki Katalonii, a także dynamiki jej zmian, które warunkowane były niestabilną sytuacją polityczną w regionie w ciągu ostatnich 10 lat (2010-2020). Za kluczowe wydarzenia obrane zostały dwa referenda niepodległościowe ${ }^{1}$ zorganizowane w Katalonii odpowiednio 11 września 2014

${ }^{1}$ Termin „referendum” w kontekście oddania przez społeczeństwo głosu w sprawie uzyskania przez Katalonię niepodległości użyty został na podstawie terminologii zastosowanej przez Elżbietę Lesiewicz w artykule "Independence Referenda in Catalonia and Their Political Significance" (2020). Nie ma jednak zgody co do określania katalońskiego głosowania pojęciem „referendum”, jako że nie miało ono podstawy prawnej i ostatecznie uznane 
roku oraz 1 października 2017 roku, których reperkusje zaobserwować można przede wszystkim w gospodarce. Zgodnie z podjętym celem artykułu postawione zostały trzy pytania badawcze:

1. Czy i w jakim stopniu dążenia niepodległościowe wpłynęły na stan katalońskiej gospodarki w latach 2010-2020?

2. Które z wybranych do analizy wskaźników makroekonomicznych znacząco zmieniły swoją wartość?

3. Czy zmiany sytuacji katalońskiej gospodarki wynikające z przeprowadzonego głosowania w 2014 roku były porównywale do zmian po wydarzeniach z roku 2017 ?

By odpowiedzieć na pytania badawcze, podjęto studia literaturowe oraz przeprowadzono analizę danych ekonomicznych. Artykuł podzielony został na trzy części: w pierwszej opisany został zarys dążeń niepodległościowych w Katalonii. Druga część poświęcona jest charakterystyce katalońskiej gospodarki z włączeniem kluczowych wielkości demograficznych i podstawowych wskaźników makroekonomicznych. W trzeciej części porównano wybrane wskaźniki makroekonomiczne Katalonii w latach 2010-2020. Wnioski dotyczące analizy wskaźnikowej zestawione z dyskusją w kontekście dotychczasowych badań poświęconych tematyce niepodległości w Katalonii zaprezentowane zostały w ostatniej części artykułu: Konkluzje.

\section{Podstawy dążeń niepodległościowych w Katalonii}

W ciągu ostatnich lat w związku z procesem globalizacji i osłabieniem pozycji państw nrodowych problem autonomii regionalnej doczekał się wielu opracowań naukowych, np. Wiszniowski, 2013; Kuchciak, 2017, w których jednym z ciekawszych przypadków niezmiennie pozostaje Hiszpania. Pod względem prawnym instytucjonalne ramy dla powszechnej autonomii regionalnej tego państwa stanowi obecnie

zostało przez hiszpański Trybunał Konstytucyjny za nielegalne. W opracowaniach naukowych zamiennie dla terminu ,referendum” pojawia się np. określenie „symboliczne głosowanie” (artykuł Rozalii Sasor „Katalońska pamięć historyczna i kryzys hiszpańskiej państwowości. Przyczynek” z roku 2015). 
Konstytucja Hiszpanii z 29 grudnia 1978 roku, w której najważniejszy w tym kontekście jest art. 2: „Konstytucja opiera się na nierozerwalnej jedności narodu hiszpańskiego, wspólnej i niepodzielnej ojczyzny wszystkich Hiszpanów, a także uznaje i zapewnia prawo do autonomii stanowiących go narodowości i regionów oraz solidarność między wszystkimi" (Konstytucja Hiszpanii z 27 grudnia 1978. Tłum. Tadeusz Mołdawa, Biblioteka Sejmowa, 2021).

Zgodnie z obowiązującym i najwyższym aktem prawnym w Hiszpanii jest ona państwem niepodzielnym oraz posiadającym jeden nierozerwalny naród. Jednocześnie artykuł 2 Konstytucji gwarantuje prawo do autonomii wszystkich jej regionów oraz zamieszkujących je narodowości. „Hiszpańskie wspólnoty autonomiczne mają uprawnienia prawotwórcze i administracyjne, z których korzystają na zasadzie wyłączności. Do ich wykonywania konstytucja wyposaża ponadto w określony zespół uprawnień finansowych, pozwalających zdobywać, gromadzić i wydatkować środki pieniężne, chociaż aktualnie z większej autonomii finansowej korzystają tylko Nawarra i Kraj Basków" (Wlaźlak, 2016: 15). Mimo że gwarantowana na mocy prawa autonomia regionalna powinna więc z założenia rozładowywać napięcia społeczne i minimalizować ruchy separatystyczne, obecnie stanowi ona raczej powód wielu konflików między regionami, które za podstawę mają zarówno aspekty kulturowe, jak i ekonomiczne.

Dążenia niepodległościowe w Katalonii motywowane były zarówno chęcią poszerzenia autonomii, jak i uzyskania niepodległości w celu utworzenia nowego organizmu państwowego, przy czym należy pamiętać, że nie wszyscy Katalończycy pragną niepodległego państwa. Mieszkańcy regionu dzielą się na zwolenników dwóch nurtów: niepodległościowego (separatystycznego) oraz unionistycznego. Tym niemniej, jak pisze Ewa Kulak, manifestacje poczucia odrębności Katalończyków w stosunku do narodów zamieszkujących inne regiony Półwyspu Iberyjskiego sięgają czasów średniowiecza, kiedy Katalonia stanowiła zlepek małych terytoriów zaludnionych głównie w wysoko położonych dolinach górskich (Kulak, 2016: 7). Na przestrzeni kolejnych wieków jednymi z najważniejszych wydarzeń, które ukształtowały współczesną Katalonię, były m.in. unia katalońsko-aragońska 
w 1137 roku, kiedy zdecydowanie bardziej rozwiniętym regionem była Katalonia niż uboga i górzysta Aragonia, a konflikt o podłożu ekonomiczym dotyczył chęci dominacji nad nowo powstałym królestwem. Podobny skutek miała także (zawiązana w 1469 roku) unia Korony Aragonii z Królestwem Kastylii, kiedy centrum władzy królewskiej znalazło się poza granicami Korony (Kulak, 2016: 59). Jednak pierwszy poważny konflikt między Katalonią a Hiszpanią, czyli wojnę żeńców (Guerra dels Segadors, 1640-1852), datuje się na koniec panowania Filipa III. Jego przyczynę stanowiły obciążenia podatkowe oraz konieczność utrzymania przez Katalończyków oddziałów hiszpańskiej armii zaangażowanej w wojnę trzydziestoletnią, a zatem poczucie niesprawiedliwości ekonomicznej (Tuñón de Lara, 1982: 234). Analizując zależności między Katalonią a Hiszpanią, pamiętać należy również o wojnie o sukcesję hiszpańską z początku XVIII wieku, w następstwie której w roku 1718 wprowadzone zostały królewskie dekrety ustanawiające Nowy Plan (Nueva Planta), znoszące m.in. regionalne przywileje (Sasor, 2015: 89). W odniesieniu do wspomnianych wyżej swobód, dla Katalonii znaczący był także wiek XX, a zwłaszcza wojna domowa w latach 1936-1939 i będąca jej wynikiem dyktatura generała Francisco Franco likwidująca regionalne autonomie.

W kontekście współczesnych dążeń niepodległościoweych przełomowy dla Katalonii był rok 2006, kiedy w referendum 18 czerwca 2006 większością 79\% przyjęty został nowy Statut dla regionu (Jackiewicz, 2013: 408), mający poszerzać zakres autonomii m.in. o zmiany w systemie finansów, tj. ograniczenie kontrybucji wnoszonych przez Katalonię do budżetu centralnego. Na wniosek posłów z Partii Ludowej oraz rządów niektórych hiszpańskich wspólnot autonomicznych nowy Statut został skierowany do Trybunału Konstytucyjnego, który zakwestionował część zawartych w nim zapisów dotyczących poszerzenia autonomii. Największy konflikt wywołało wykreślenie słowa „naród”, mającego określać społeczność katalońską. W konsekwencji posunięcie to zostało odczytane, ,jako godzące w ich [Katalończyków - przyp. M. K.] prawa, poczucie przynależności narodowej, a samemu Trybunałowi przypięto łatkę bycia upolitycznionym oraz podporządkowanym jedynie władzy centralnej w Madrycie" 
(Kalinowski, 2016: 185). Należy jednak pamiętać, że zawarte w Statucie sformułowanie „naród” nie było zgodne z obowiązującą Konstytucją Hiszpanii, która zakłada, że jest tylko jeden naród - hiszpański. Kolejne lata to kontynuacja walki o poszerzenie katalońskiej autonomii. I tak 23 grudnia 2013 roku kataloński parlament uchwalił „deklarację suwerenności”, którą poparły głównie ugrupowania nacjonalistyczne i regionalistyczne (Kozłowska-Socha, 2014: 193). Deklaracja została zgłoszona do Trybunału Konstytucyjnego, a ten ogłosił, że jest ona nielegalna poprzez niezgodność z hiszpańską konstytucją.

Odpowiedź rządu katalońskiego pojawiła się 19 września 2014 roku, kiedy tamtejszy parlament zdecydowaną większością przegłosował nadanie prezydentowi Genaralitat możliwości przeprowadzenia „konsultacji ze społeczością katalońską dotyczących niepodległości Katalonii”. Pod koniec września 2014 roku Artur Mas (ówczesny prezydent Generalitat) podpisał dekret umożliwiający przeprowadzenie społecznego głosowania (nieprzychylnie potraktowanego przez rząd hiszpański). Mimo niskiej frekwencji wynoszącej ok. 35-37\%², większość uczestniczących w plebiscycie 9 listopada 2014 roku opowiedziała się za niepodległością Katalonii. Rząd centralny, zaniepokojony wzrostem sympatii separatystycznych, po raz kolejny złożył wniosek do Trybunału Konstytucyjnego. Dwie wydane w następstwie uchwały dotyczyły dopuszczalności skargi rządowej oraz zawieszenia zarówno dekretu katalońskiego rządu, mającego za cel zorganizowanie referendum niepodległościowego 9 listopada 2014 roku, jak i zawieszenie ustawy referendalnej (Kochanecki, 2018: 152). W reakcji na działania rządu centralnego społeczność Katalońska 11 września 2015 roku wyszła na ulice Barcelony w ramach jednej z największych manifestacji popierających dążenia niepodległościowe. Jeszcze w tym samym miesiącu odbyły się przyspieszone wybory do lokalnego parlamentu z rekordową frekwencją sięgającą $77 \%$, po których wybrany

${ }^{2}$ „Dokładna frekwencja jest nieznana (ok. 35\%), gdyż organizatorzy nie mogli posługiwać się oficjalnym spisem wyborców. Głosujący odpowiadali na pytania: „Czy chce Pan/Pani, żeby Katalonia była państwem?” i „Czy chce Pan/ Pani, żeby była niepodległa?" (Husar, 2016: 216). 
prezydent Generalitat Carles Puigdemont zapowiedział chęć przeprowadzenia referendum konstytucyjnego 1 października 2017 roku. Głosowanie odbyło się w zaplanowanym czasie, jednak nie tylko nie zostało uznane przez rząd hiszpański, ale było także blokowane przez uniemożliwienie oddania głosów w lokalach wyborczych. 2 października 2017 roku podane zostały wstępne wyniki, które pokazały, że w referendum wzięło udział ok. 42\% uprawnionych do głosowania obywateli i aż 90\% opowiedziało się za niepodległością (Kazimierczuk, Bartkiewicz, Mikulski, 2017).

Przeprowadzenie plebiscytu pociągnęło za sobą skutki karne, a mianowicie Sąd Najwyższy Hiszpanii 14 października 2019 roku skazał dziewięciu polityków oraz działaczy separatystycznych na kary od 9 do 13 lat więzienia. Podstawą prawną dla ogłoszonego wyroku było oskarżenie o „bunt i sprzeniewierzenie środków publicznych”, jednocześnie Carles Puigdemont został objęty europejskim nakazem aresztowania. Mimo uzyskania w tym samym roku mandatu w Parlamencie Europejskim, tenże Parlament, uwzględniając wniosek przekazany przez prezesa Sądu Najwyższego Hiszpanii, podjął decyzję o uchyleniu immunitetu Puigdemonta (Parlament Europejski, Sprawozdanie w sprawie wniosku o uchylenie immunitetu Carlesa Puigdemonta i Casamajó, 24.02.2021).

Aktualna sytuacja polityczna w Katalonii jest w dalszym ciągu wysoce niestabilna. Katalońscy nacjonaliści tracą poparcie społeczeństwa, które jest zmęczone nie tylko panującym chaosem i nieporozumieniami pomiędzy rzadzącymi, ale także skutkami pandemii SARS-CoV-2, która doprowadziła do złej sytuacji gospodarczej zarówno regionu, jak i całego kraju. Ponadto większość Katalończyków nie jest już tak bardzo zainteresowana oddzieleniem się od Hiszpanii: „według różnych ośrodków badań opinii, poparcie dla niepodległości Katalonii, które kilka lat temu sięgało 49 proc., spada. Dzisiaj za oderwaniem od Hiszpanii jest 42-43\% Katalończyków, a przeciw 49-50\%" (Stasiński, 2021). Skutki wymienionych wcześniej działań widoczne są jednak przede wszystkim w regionalnej gospodarce, która jeszcze w 2017 roku była jedną z najprężniej działających w kraju, a obecnie traci nawet zainteresowanie partnerów międzynarodowych. 
Katalonia niezmiennie stanowi jeden z najważniejszych regionów monarchii hiszpańskiej, a obecna sytuacja wymaga mądrego dialogu z rządem hiszpańskim oraz ponownego określenia zależności tego regionu $\mathrm{z}$ centrum.

\section{Charakterystyka katalońskiej gospodarki}

\subsection{Podstawowe informacje o regionie}

Katalonia zajmuje powierzchnię $32108 \mathrm{~km}^{2} \mathrm{w}$ północno-zachodniej części Półwyspu Iberyjskiego (Eures, 2020), granicząc z Francją i Andorą oraz z regionami autonomicznymi: Aragonią i Walencją. Stolica Katalonii, Barcelona, to największy port turystyczny i handlowy basenu Morza Śródziemnego, łączący Hiszpanię i Europę z krajami północno-zachodniej Afryki, stanowiąc jednocześnie punkt wyjściowy transferu cargo do Ameryki Południowej. Położenie geograficzne to jeden z ważniejszych komponentów atrakcyjności Katalonii. Realnie wpływa na kształt gospodarki we wszystkich jej sektorach oraz na politykę prowadzoną zarówno wewnątrz regionu, jak i poza jego granicami. Jak pisze Robert Wiszniowski, ,jest to region wyżynno-górzysty, z nielicznymi nizinami w dolinie rzeki Ebro. Do historycznej Katalonii należy również większa część departamentu Pireneje Wschodnie we Francji, tzw. Katalonia Północna. Na terenie tego departamentu leży również katalońska eksklawa Llívia" (Wiszniowski, 2013: 97). W celu określenia wszystkich krain katalońskojęzycznych, które niegdyś były powiązane z Koroną Aragonii, obecnie używa się terminu Països Catalans.

Katalonia jest regionem charakteryzującym się różnorodnym krajobrazem, na który skaładają się zarówno długie piaszczyste plaże, kamieniste wybrzeże (np. miasteczka Cadaques czy Port Lligat), niziny, mokradła oraz góry, w których najwyższym szczytem jest Pica d'Estats, znajdujący się na granicy francuskiej. Jego wysokość to 3143 m n.p.m. (Pirineus: 2021). Obszary nizinne znajdują się wyłącznie na wybrzeżu i w dolinach rzek (głównie Ebro, ale także Llobregat), a tereny wyżynne w głębi lądu. Takie ukształtowanie sprzyja przede wszystkim turystyce, ale także gospodarce, wpływając szczególnie na 
rolnictwo oraz przemysł. Region ten leży w strefie klimatu podzwrotnikowego, umiarkowanie wilgotnego, który umożliwia rozwój m.in. sadownictwa (uprawa oliwek, cytrusów i winorośli). W mniejszym zakresie utrzymana jest tradycyjna hodowla bydła oraz pasterstwo górskie (Wiszniowski, 2013: 98).

Zgodnie z danymi Statistical Institute of Catalonia liczba mieszkańców Katalonii w 2020 roku wyniosła 7722 203, co stanowi bowiem 16,3\% całej populacji Hiszpanii ${ }^{3}$ (oraz odpowiednio 1,73\% ludności UE). Rozłożenie mieszkańców na poszczególne prowincje katalońskie nie jest równomierne: prowincję Barcelony zamieszkuje 73,86\% ludności katalońskiej (5 703334 mieszkańców), prowincję Tarragony 10,60\% (818 702 mieszkańców), prowincję Girony 9,91\% (765 554 mieszkańców), prowincję Lleidy 5,63\% (434 613 mieszkańców). Istotna jest także liczba imigrantów: cudzoziemcy stanowią bowiem 16,2\% mieszkańców Katalonii ogółem (Statistical Institute of Catalonia, 2020) ${ }^{4}$.

${ }^{3}$ Populacja Hiszpanii w roku 2020: 47332614 (Statistical Institute of Catalonia, 2020).

${ }^{4}$ Badaczami, którzy przedstawiają charakterystykę napływu imigrantów do Katalonii oraz ich znaczenie w kontekście kulturowym i ekonomicznym, są m.in. Karolina Golemo (2017) oraz Vicent Climent-Ferrando (2012). 


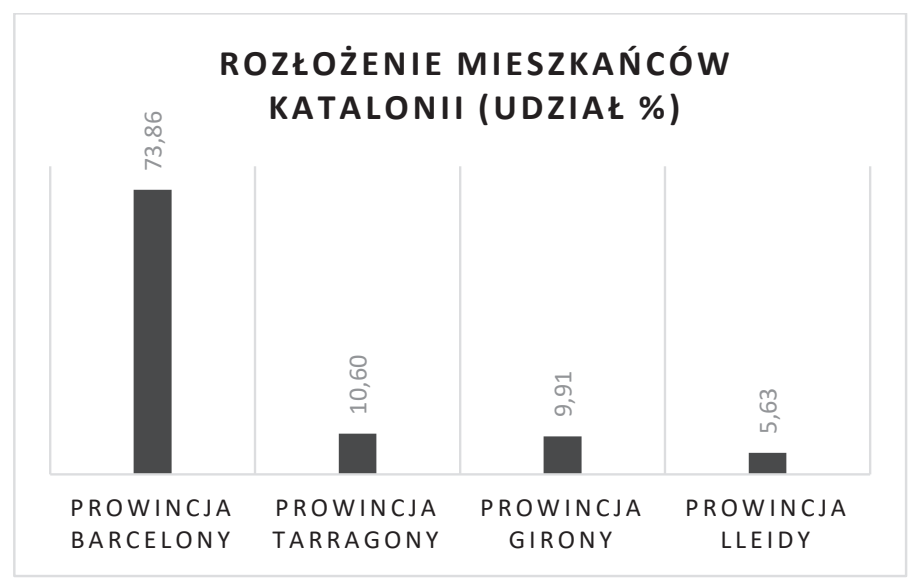

Wykres 1. Opracowanie własne na podstawie Population on 1 January. Provinces (Statistical Institute of Catalonia, 2020)

Według Badania Aktywności Ludności (la Encuesta de Población Activa) za trzeci kwartał 2019 roku (najnowsze dostępne dane), przeprowadzonego przez Narodowy Instytut Statystyki w Katalonii, w roku 2019 było 3884500 osób aktywnych zawodowo, z czego 3462400 to osoby zatrudnione, a 422100 bezrobotni. Najwięcej pracujących koncentrowało się w sektorze usług $(75,00 \%)$, następnie w przemyśle $(17,90 \%)$, budownictwie $(5,52 \%)$ i rolnictwie $(1,58 \%)$ (Eures, 2020).

\subsection{Charakterystyka katalońskiej gospodarki}

Katalońska gospodarka poddawana była licznym analizom jakościowym i ilościowym, a tematem zajmowali się m.in. Antoni Castells (1998), Jordi Pons i Novell, Ramon Tremosa i Balcells (2005), Jeroen Oskam (2014), Brandon M. Boylan (2015) czy Xavier Cuadras Morató (2017). W pracach wyżej wymienionych autorów pojawia się nie tylko ogólna jej charakterystyka wraz z analizą najważniejszych wskaźników makroekonomicznych, ale także omawiane są kwestie 
dotyczące prawa podatkowego, redystrybucji dochodu oraz gospodarcze skutki dążeń niepodległościowych. Dla każdego z opracowań podstawę do charakterystyki sytuacji ekonomicznej niezmiennie stanowi geopolityka.

Mimo stosunkowo małego znaczenia pierwszego sektora gospodarki (rolnictwo) w kontekście sytuacji ekonomicznej, warto zauważyć, że jednym z najsłynniejszych katalońskich produktów jest musujące wino cava, eksportowane do wielu krajów europejskich, m.in. Francji, Włoch, Polski etc. Do uznanych producentów i dystrybutorów cavy są zaliczani m.in.: Bodegues Sumarroca oraz Castelo de Pedregosa, a jedną z najstarszych winnic, która zajmuje się uprawą winorośli od XVIII wieku, jest Cavas J. Hill (Generalitat de Catalunya, 2021).

Dla drugiego sektora gospodarki (przemysł) istotna jest znaczna aktywność w podsektorach: chemicznym (np. Air-Val International, Croda Iberica), motoryzacyjnym (Altran Innovacion Sociedad Limitada, Asistencias y Suministros Mecanicos), produkcji sprzętu elektrycznego (np. Continental Automotive Spain) oraz sprzętu dedykowanego działalności IT (np. Oracle Iberica SRL). Istotne znaczenie ma również przemysł wydawniczy i budownictwo, z takimi przedsiębiorstwami jak Planeta Corporacion SL czy Roca Corporacion Empresarial (Generalitat de Catalunya, 2021). Zgodnie z raportem Catalan Economy The Strength of an Innovative and Outward-looking Nation (2020) warto zauważyć, że zatrudnienie w przemyśle wysokiej i średniowysokiej technologii stanowi 6,4\% ogółu zatrudnienia, co stanowi odsetek wyższy niż we Włoszech (6,3\%), Francji (4,2\%) i Hiszpanii (4,0\%).

$\mathrm{W}$ trzecim sektorze gospodarczym (usługi) najistotniejsza jest turystyka i związana z nią działalność. W 2018 roku najczęściej odwiedzanym europejskim krajem była Hiszpania - 301 mln wykupionych noclegów, co stanowi 22,6\% łącznej liczby noclegów w europejskiej gospodarce. Ponad 6 na 10 z tych noclegów przypadło na trzy regiony: Katalonię, Wyspy Kanaryjskie i Baleary (Tendencje w zakresie liczby noclegów w turystycznych obiektach noclegowych w UE-27, lata 2005-2018, UE-27 Eurostat, 2020). Raport za 2019 rok dotyczący katalońskiej gospodarki i jej otoczenia (Nota de Conjuntura Econòmica, 2020) wykazuje, że liczba turystów odwiedzających 
Katalonię systematycznie wzrasta. W 2019 roku ten region Hiszpanii odwiedziło 19,38 mln osób (co stanowiło wzrost o 0,8\% względem roku 2018). W 2020 roku liczba odwiedzających spadła do 3,88 mln (Statista, 2021), a bezpośrednią przyczynę spowolnienia turystyki stanowi pandemia SARS-CoV-2 i wynikające z niej obostrzenia dotyczące mobilności społeczeństw.

Rozwijająca się branża turystyczna w Katalonii swój sukces zawdzięcza także biznesowi: w Hiszpanii (podobnie jak w innych państwach) działa Convention Bureau, któremu przewodzi Catalunya Convention Bureau (CCB) (catalunya.com, 2021), odpowiadająca za organizację targów i kongresów dla przedsiębiorców oraz sektora badawczo-rozwojowego. Warto zauważyć, że opracowanie i wykorzystywanie nowych technologii w ramach $\mathrm{B}+\mathrm{R}$ w Katalonii jest zasługą nie tylko przedsiębiorców i inwestorów, ale także Sieci Parków Technologicznych i Naukowych (Xarxa de Parcs Cientifics i Tecnologics de Catalunya, XPCAT). Katalonia traktowana jest także jako jeden z lepszych w Europie ośrodków akademickich, który oferuje studia związane z ICT (Information and Communication Technologies), IoT (Internet of Things) oraz z nowymi technologiami, co przyczynia się także do dobrego funkcjonowania XPCAT. CCB przypisuje się niezwykle istotne znaczenie, biorąc pod uwagę, że w tym regionie Hiszpanii swoją siedzibę mają trzy firmy z hiszpańskiego indeksu Ibex-35 (jeszcze w roku 2017 było ich 7): Cellnex Telecom, Grifols oraz Armirall. Inwestycje w badania i rozwój oraz wysoki poziom wskaźników innowacji są jedną z podstawowych przyczyn tak chętnie podejmowanej współpracy między inwestorami zagranicznymi a tym regionem Hiszpanii.

\subsubsection{Współpraca międzynarodowa}

Położenie geograficzne ma także istotny wpływ na turystykę oraz handel międzynarodowy. W Katalonii lokuje się ok. 21\% wszystkich inwestycji zagranicznych, co łącznie z wysokim PKB regionu ustanowiło Barcelonę siedzibą Hiszpańskiej Izby Handlowej (Maliszewski, 2017). Przemysł kataloński produkuje głównie na eksport, w którym największą część stanowią wyroby chemiczne i farmaceutyki, a także przemysł maszynowy. Zgodnie z danymi z 2020 roku (Generalitat de Catalunya) eksport kataloński stanowi 25,4\% całego eksportu Hiszpanii, podczas gdy import 
kataloński stanowi $27,7 \%$. Sektor chemiczny odpowiada za 26,5\% katalońskiego eksportu i $24,5 \%$ importu. Jego waga w stosunku do całości sektora chemicznego w Hiszpanii wynosi $48,1 \%$ w przypadku eksportu i $41,2 \%$ w przypadku importu (Generalitat de Catalunya, 2020). Sukcesywny wzrost wskaźnika eksportu świadczy nie tylko o wysokim stopniu umiędzynarodowienia, ale także o otwartości katalońskiej gospodarki. Jak wynika z raportów Institut d'Estadística de Catalunya (2020), najszybciej rozwijającym się rynkiem zagranicznym dla katalońskich przedsiębiorstw jest Azja (przyrost 8,9\%), następnie Ameryka Północna (5,3\%) oraz Europa $(4,5 \%)$. Katalonia oprócz wyrobów chemicznych i farmaceutyków eksportuje także zasoby spożywcze.

Współpraca międzynarodowa przejawia się również w świadomym lokowaniu fabryk i siedzib firm zagranicznych w tym regionie Hiszpanii, czego bezpośrednią przyczyną jest wysoki poziom innowacji oraz rozwoju technologicznego. Według Generalitat de Catalunya (2020) w samej Katalonii działa niemal 1000 niemieckich firm, w tym spółka córka Volkswagen SEAT z trzema fabrykami zatrudniającymi ok. 14000 osób. Innymi niemieckimi przedsiębiorstwami działającymi na terenie Katalonii są koncerny chemiczne Bayer i BASF oraz sieć supermarketów Lidl. Francuski biznes reprezentuje w Katalonii przedsiębiorstwo Alstom, koncern energetyczny produkujący głównie tramwaje i pociągi z wykorzystaniem nowych technologii. Także w Katalonii swoją główną siedzibę ma amerykański koncern Cargill, który w Hiszpanii zajmuje się produkcją i marketingiem opakowań żywności, operuje w branży żywienia zwierząt oraz wszelkiego sprzętu bioprzemysłowego (cargill.com, 2021). Rozpoznawalną marką, która swoje hiszpańskie centrum ustanowiła w Katalonii, jest szwajcarski koncern spożywczy Nestlé z główną siedzibę w Gironie (Generalitat de Catalunya, 2021). Wymienione wyżej przedsiębiorstwa stanowią tylko niewielki procent wszystkich firm zagranicznych z centralą na rynek hiszpański umiejscowioną właśnie w Katalonii i tym samym potwierdzają międzynarodową współpracę regionu w różnych sektorach gospodarki. Współpraca międzynarodowa to także lokowanie oddziałów katalońskich firm w innych krajach Europy i świata. Firmy kojarzone z Katalonią obecne na rynku międzynarodowym to m.in. Tous, Vueling oraz Ros Roca SA. 


\section{Opis i analiza wybranych wskaźników makroekonomicznych Katalonii $^{5}$ w latach 2010-2020}

Najbardziej kompleksowym i powszechnie używanym miernikiem całkowitej produkcji dóbr i usług danego kraju jest Produkt Krajowy Brutto (PKB), stanowiąc niezastąpione źródło danych do analiz sytuacji ekonomicznej (Krugman, Wells, 2012: 48-49, 54). Równie ważnym w analizie wskaźnikiem świadczącym o rozwoju, stagnacji lub regresie badanej gospodarki jest stopa wzrostu gospodarczego, zwyczajowo nazywana m.in. ,wzrostem PKB (w ujęciu realnym)” i „,(realnym) tempem wzrostu PKB” (Czarny, 2011).

$\mathrm{W}$ tabeli 1 zestawione zostały wartości PKB w ujęciu realnym w Katalonii w latach 2010-2020.

\begin{tabular}{|c|c|c|c|c|c|c|c|c|c|c|c|}
\hline $\begin{array}{c}\text { WSKAŹ- } \\
\text { NIK }\end{array}$ & 2010 & 2011 & 2012 & 2013 & 2014 & 2015 & 2016 & 2017 & 2018 & 2019 & 2020 \\
\hline $\begin{array}{l}\text { PKB realny } \\
\text { wyliczony } \\
\text { przy użyciu } \\
\text { CPI } \\
\text { (mln Euro) }\end{array}$ & 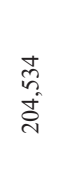 & $\begin{array}{l}\stackrel{a}{0} \\
\infty \\
\stackrel{0}{-}\end{array}$ & $\begin{array}{l}\infty \\
0 \\
0 \\
\infty \\
\infty\end{array}$ & $\begin{array}{l}\infty \\
\frac{\infty}{1} \\
\infty \\
\infty\end{array}$ & $\begin{array}{l}n \\
\tilde{\sigma} \\
\infty \\
\infty\end{array}$ & 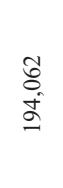 & 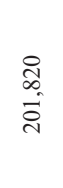 & 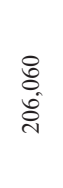 & 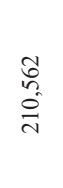 & $\begin{array}{l}0 \\
\infty \\
\infty \\
\sim \\
\sim\end{array}$ & 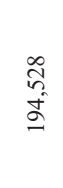 \\
\hline
\end{tabular}

Tabela 1. Wartości realnego PKB dla regionu Katalonia w latach 2010-2020. Opracowanie własne na podstawie danych z Institut d'Estadística de Catalunya oraz Instituto Nacional de Estadística

${ }^{5} \mathrm{~W}$ analizie wykorzystane zostały dane pobrane z Instytutu Statystyki Katalonii (Institut d'Estadística de Catalunya), który jest organem statystycznym Generalitat de Catalunya. Powstał w 1989 r. (Dekret 341/1989 z 11 grudnia) i stanowi samodzielny organ o charakterze administracyjnym $z$ własną osobowością prawną. Obecnie związany z Departamentem Wiceprezydenta oraz Departamentem Ekonomii i Finansów (Institut d'Estadística de Catalunya, 2021). Instytut odpowiada za planowanie, normalizację, koordynację oraz zarządzanie systemem statystycznym w Katalonii. 
W latach 2010-2019 można zauważyć, że wartość PKB realnego wzrasta. Wyjątkiem ogólnej tendencji są lata 2011-2013, kiedy zanotowany został nieznaczny spadek wskaźnika, związany bezpośrednio z kryzysem zadłużenia w strefie euro (ang. sovereign debt crisis).

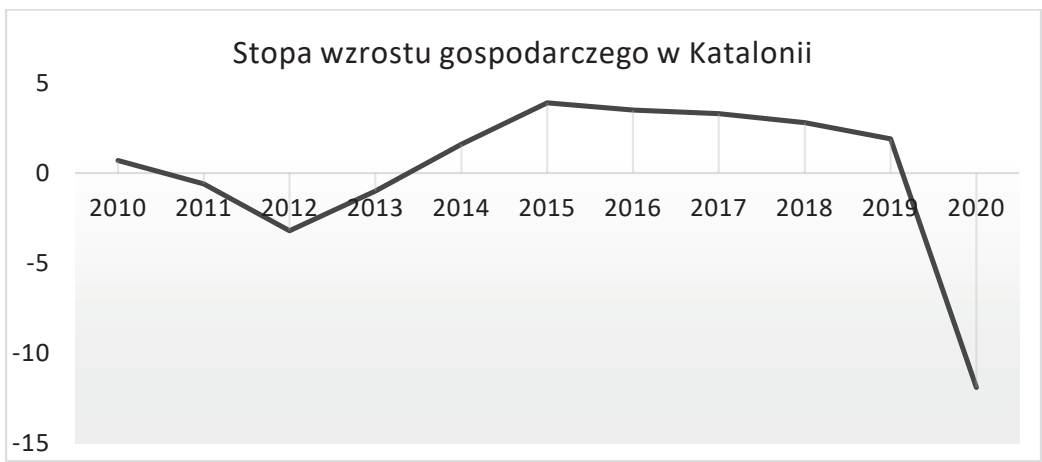

Wykres 2. Opracowanie własne na podstawie danych z Institut d'Estadística de Catalunya (2021)

Znacznie większe wahania prezentuje stopa wzrostu gospodarczego. Na wykresie 2 przedstawiono jej zmianę świadczącą o niestabilnej sytuacji gospodarczej: pierwszy spadek w latach 2010-2012 spowodowany był (podobnie jak spadek większości wskaźników makroekonomicznych) przywołanym już kryzysem zadłużenia w strefie euro. Skrajnie niestabilna sytuacja gospodarczo-finansowa wpłynęła na stan gospodarki szczególnie w krajach na południu Europy. Natomiast od roku 2015 do 2019 w Katalonii widoczny jest powolny regres, na który wpływ miały m.in. wydarzenia motywowane dążeniami niepodległościowymi, a w szczególności obawy inwestorów przed separacją regionu, o czym podczas prezentacji raportu na temat perspektyw ekonomicznych Hiszpanii w 2017 wspominała stojąca na czele misji Międzynarodowego Funduszu Walutowego tego kraju Andrea Schaechter (Dziennik Gazeta Prawna, 2017). Znaczący spadek w roku 2019 oraz 2020 spowodowany jest pandemią SARS-CoV-2. 
Równie istotnym wskaźnikiem makroekonomicznym mającym związek z rozwojem gospodarczym państwa (bądź regionu) jest stopa bezrobocia. Wysokość stopy bezrobocia jest warunkowana m.in. rozwojem technologicznym oraz wprowadzaniem modernizacji w miejscach pracy, co nie tylko prowadzi do wzrostu zatrudnienia, ale także pozytywnie wpływa na rozwój przedsiębiorstwa, a tym samym gospodarki.

\begin{tabular}{|c|c|c|c|c|c|c|c|c|c|c|c|}
\hline WSKAŹNIK & $\mathbf{2 0 1 0}$ & $\mathbf{2 0 1 1}$ & $\mathbf{2 0 1 2}$ & $\mathbf{2 0 1 3}$ & $\mathbf{2 0 1 4}$ & $\mathbf{2 0 1 5}$ & $\mathbf{2 0 1 6}$ & $\mathbf{2 0 1 7}$ & $\mathbf{2 0 1 8}$ & $\mathbf{2 0 1 9}$ & $\mathbf{2 0 2 0}$ \\
\hline $\begin{array}{c}\text { Stopa bezrobo- } \\
\text { cia (wyrażona } \\
\text { w \%) }\end{array}$ & 17,7 & 19,2 & 22,5 & 23,1 & 20,3 & 18,6 & 15,7 & 13,4 & 11,5 & 11,0 & 12,6 \\
\hline $\begin{array}{c}\text { Poziom inflacji } \\
\text { (udział \% rok } \\
\text { do roku) }\end{array}$ & 1,8 & 3 & 2,8 & 1,7 & 0,1 & $-0,1$ & 0,1 & 2,2 & 1,9 & 0,9 & $-0,5$ \\
\hline
\end{tabular}

Tabela 2. Zestawienie wartości stopy bezrobocia oraz poziomu inflacji w Katalonii w latach 2010-2020. Opracowanie własne na podstawie danych z Institut d'Estadística de Catalunya (2021)

Największy wpływ na poziom bezrobocia nie tylko w Katalonii, ale także Hiszpanii i innych państwach Europy i świata miał kryzys gospodarczo-finansowy (w Stanach Zjednoczonych 2008, w Europie 2009 rok). W jego konsekwencji wartości wskaźników w niektórych krajach sięgały ponad $20 \%$. W Katalonii w analizowanym przedziale czasowym najwyższa stopa bezrobocia $(23,1 \%)$ notowana była w roku 2013. Jednak już od roku 2014, mimo wydarzeń związanych z dążeniami niepodległościowymi, widoczna jest tendencja spadkowa. Tym samym można stwierdzić, że zarówno „konsultacje rządu ze społeczeństwem" w roku 2014 w sprawie niepodległości Katalonii, jak i referendum w roku 2017 nie miały istotnego wpływu na bezrobocie w tym regionie Hiszpanii. Dynamika inflacji nie przekracza w analizowanym okresie 3\%, co pozwala zaklasyfikować ją do inflacji pełzającej, nieprzynoszącej negatywnych skutków gospodarce regionalnej. Odstępstwem są jedynie lata 2015 oraz 2020, kiedy wartości ujemne 
spowodowały krótką deflację. W roku 2015 wartość wyniosła -0,1\%, nie pogłębiła się w roku kolejnym i zależeć mogła od cyklu koniunkturalnego. W roku 2020 wartość ujemna spowodowana jest pandemią.

Podejmując analizę sytuacji gospodarczej w Katalonii, która warunkowana jest działaniami niepodległościowymi (politycznymi), należy nadmienić, że jednym z ważniejszych wskaźników są bezpośrednie inwestycje zagraniczne (BIZ). W ujęciu makroekonomicznym definiuje się je jako formę międzynarodowego przepływu kapitału, co jest także jednym z bardziej znaczących źródeł finansowania gospodarki państwa (w tym przypadku regionu) poprzez bardziej zyskowne wykorzystanie aktywów danego przedsiębiorstwa niż we własnym państwie (regionie). Katalonia jest przykładem gospodarki otwartej, umiędzynarodowionej oraz nastawionej na eksport, co w kontekście współpracy międzynarodowej daje możliwość uzyskania przewagi gospodarczej nad innymi regionami Hiszpanii.

\begin{tabular}{|c|c|c|c|c|c|c|c|c|c|c|c|}
\hline $\begin{array}{c}\text { WSKAŹ- } \\
\text { NIK }\end{array}$ & $\mathbf{2 0 1 0}$ & $\mathbf{2 0 1 1}$ & $\mathbf{2 0 1 2}$ & $\mathbf{2 0 1 3}$ & $\mathbf{2 0 1 4}$ & $\mathbf{2 0 1 5}$ & $\mathbf{2 0 1 6}$ & $\mathbf{2 0 1 7}$ & $\mathbf{2 0 1 8}$ & $\mathbf{2 0 1 9}$ & $\mathbf{2 0 2 0}$ \\
\hline $\begin{array}{c}\text { BIZ } \\
\text { (mln euro })\end{array}$ & 4890,5 & 3143,1 & 2730,4 & 3661,7 & 3064,4 & 5494,8 & 8271,7 & 3431,1 & 4326,4 & 3838,7 & 2965,0 \\
\hline
\end{tabular}

Tabela 3. Zestawienie wartości BIZ w Katalonii w latach 2010-2020. Opracowanie własne na podstawie danych z Institut d'Estadística de Catalunya (2021)

Zestawienie wartości BIZ pozwala wnioskować, że działania związane z dążeniem do niepodległości istotnie wpłynęły na wartość wskaźnika w roku 2017: zmiana z 8 271,1 mln euro do 3 431,1 mln euro stanowi odpowiednio spadek o $61 \%$. W tym samym czasie Madryt zanotował wzrost inwestycji o 133\% (Idealista News, 2020). Sytaucja polityczna w Katalonii, próby jej oddzielenia się od Hiszpanii były postrzegane i oceniane negatywnie nie tylko przez rząd w Madrycie, ale także biznesowych partnerów zagranicznych. Po ogłoszeniu wyników referendum, przeprowadzonego 1 października 2017 roku, wielu inwestorów wyrażało swój niepokój pod postacią oświadczeń i wycofało produkcję z Katalonii (jednocześnie wyprowadzając z tego regionu swój kapitał). Schemat działania 
widoczny był także w odniesieniu do przedsiębiostw państwowych, które przenosiły swoje główne siedziby do innych regionów Hiszpanii (głównie Walencji i Madrytu), jak np. Caixabank. Warto wspomnieć także o konsekwencjach tych ruchów na Giełdzie Papierów Wartościowych w Madrycie. Referendum w sprawie ogłoszenia niepodległości, przeprowadzone 1 października 2017 roku, poskutkowało falą spadków cen akcji katalońskich firm na madryckiej giełdzie łącznie o 2 miliardy euro (Rynek Inwestycji, 2017).

Stan gospodarki i szybkość jej rozwoju określa także indeks produkcji przemysłowej (IPI). Na jego podstawie szacuje się wskaźnik wykorzystania mocy produkcyjnej, który pokazuje, jaka jest różnica między rzeczywistą produkcją przemysłową w danym kraju a produkcją potencjalną. Wysoka dynamika świadczyć będzie o dobrym stanie gospodarki: produkcja przemysłowa ma wpływ m.in. na ceny akcji, co bezpośrednio motywuje potencjalnych inwestorów. Niska dynamika (a szczególnie ujemna) wykazuje niekorzystną sytuację gospodarczą. Może prowadzić do wycofania inwestycji oraz pogorszenia współpracy międzynarodowej.

\section{Indeks produkcji przemysłowej (IPI) w Katalonii w latach 2010-2020}

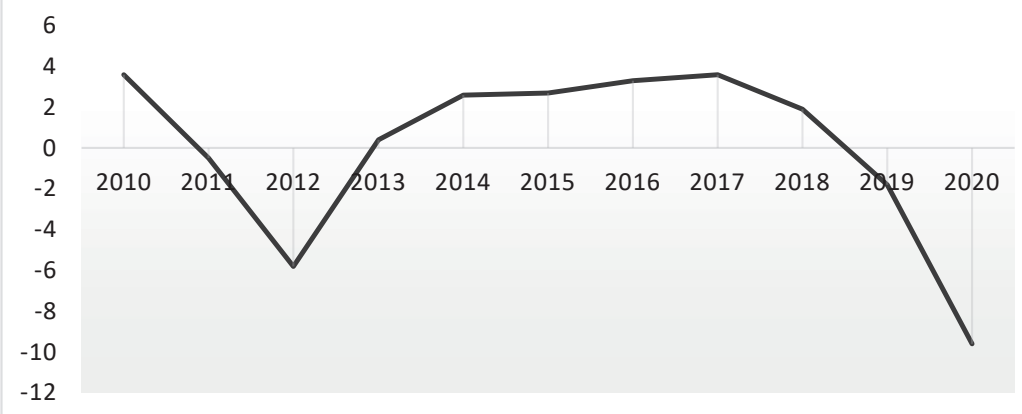

Wykres 3. Opracowanie własne na podstawie danych z Institut d'Estadística de Catalunya (2021) 
Podobne znaczenie do zmian wartości BIZ ma indeks produkcji przemysłowej, którego wyraźny spadek widoczny jest od 2017 roku i który osiągnął aktualnie niepokojącą wartość -9,6. Mimo że za tak niski poziom indeksu w 2020 roku odpowiada przede wszystkim pandemia, również niestabilna sytuacja polityczna w regionie poskutkowała znacznym jego spadkiem. Podobnego trendu nie odnotowano po „społecznych konsultacjach” w roku 2014, co może prowadzić do wniosków, że konsekwencje referendum z roku 2017, pod postacią wydania przez Sąd Najwyższy Hiszpanii wyroków pozbawienia wolności liderów katalońskiego ruchu niepodległościowego, potraktowane zostały jako zagrożenie dla prowadzenia biznesu w tym regionie Hiszpanii.

\section{Konkluzje}

Katalonia niewątpliwie należy do najlepiej rozwiniętych gospodarczo regionów w Monarchii Hiszpańskiej. Charakteryzuje się przede wszystkim sukcesywnym rozwojem przemysłu i rolnictwa, wysokim poziomem innowacji, ukształtowaniem geograficznym umożliwiającym rozwój turystyki oraz gospodarką otwartą na współpracę międzynarodową. Mimo zdecydowanej przewagi małych i średnich przedsiębiorstw region ten obfituje w aktywa dużych międzynarodowych koncernów, które swoje główne siedziby w Hiszpanii ulokowały właśnie w Katalonii, co zdecydowanie przyspiesza jej rozwój gospodarczy.

Odpowiadając na postawione w artykule pytania, na podstawie wartości analizowanych wskaźników makroekonomicznych, można stwierdzić, że sytuacja polityczna w regionie w latach 2010-2020 wpłynęła na gospodarkę nie tylko katalońską, ale także hiszpańską. Największa zaobserwowana zależność dotyczy biznesowych relacji krajowych i międzynarodowych, co potwierdzają wskaźniki BIZ oraz IPI. W obydwu przypadkach tendencja spadkowa swój początek ma w roku $2017^{6}$. Regres widoczny jest także w stopniu wzrostu gospo-

${ }^{6}$ Zauważona tendencja spadkowa widoczna od roku 2017 określona jest w przedziale lat 2010-2020 (nie zostały uwzględnione poprzednie dekady, w których również zaobserwowane mogły być zarówno tendencje spadkowe, jak i wzrost). 
darczego, który wynika pośrednio z braku zagranicznych inwestycji. Działania separatystów nie wpłynęły natomiast na wskaźniki: PKB, inflację oraz poziom bezrobocia, które kształtują się zgodnie z kierunkiem katalońskiej (i tym samym hiszpańskiej) koniunktury.

W kontekście oddziaływania sytuacji politycznej na realny stan gospodarki można stwierdzić, że wydarzenia w roku 2014, kiedy odbyły się „konsultacje” rządu katalońskiego ze społeczeństwem w sprawie uzyskania przez Katalonię niepodległości, oraz wydarzenia w roku 2017, kiedy przeprowadzono w regionie nielegalne referendum niepodległościowe, miały różny skutek ekonomiczny. Zdecydowane pogorszenie (na przykładzie wybranych wskaźników) zaobserwowano jedynie po roku 2017.

Gospodarcze skutki działań niepodległościowych w Katalonii odczuwane są w regionie aż do roku 2021, a dodatkowym czynnikiem negatywnie wpływającym na i tak już niestabilną sytuację gospodarczą jest pandemia SARS-CoV-2. W ciągu kolejnych lat konieczny jest więc mądry dialog przedstawicieli rządów katalońskiego oraz hiszpańskiego w celu ustabilizowania nie tylko gospodarki i polityki, ale przede wszystkim odzyskania zaufania społeczeństwa i ponownego otwarcia na rozwój państwa i regionu.

\section{Bibliografia}

\section{Akty prawne}

Konstytucja Hiszpanii z 27 grudnia 1978, tłum. T. Mołdawa, Wydawnictwo Sejmowe, Warszawa 1993. Tekst wraz z ostatnią zmianą z 27 sierpnia $1992 \mathrm{r}$.

\section{Druki zwarte}

CASTELLS, A. (1998), Les relacions fiscals de Catalunya amb Espanya. Algunes reflexions en el context europeu, Editorial Proa, Barcelona.

CLIMENT-FERRANDO, V. (2012), Immigration in Catalonia in Search of a Public Philosophy, Interdisciplinary Research Group on Immigration (GRITIM-UPF), Universitat Pompeu Fabra. 
CUADRAS-MORATÓ, X. (2017), „The Catalan Economy. Crisis, Recovery and Policy Challenges", mBank - CASE Seminar Proceedings 0145, CASE-Center for Social and Economic Research, Warszawa.

CZARNY, B. (2011), Podstawy ekonomii, Polskie Wydawnictwo Ekonomiczne, Warszawa.

HUSAR-POLISZUK, W. (2020), Katalończycy. Od budowy własnej tożsamości do independentyzmu $w$ regionie, FNCE, Chomęcice.

JACKIEWICZ, A. (2013), Kontrowersje konstytucyjnoprawne i polityczne wokót ustroju terytorialnego Królestwa Hiszpanii. Ewolucja czy stagnacja? w: Bożyk, S. (red.), Aktualne problemy reform konstytucyjnych, Wydawnictwo Temida 2, Białystok.

KOZŁOWSKA-SOCHA, Z. (2014), Krajobraz historyczno-polityczny separatystycznej Katalonii, Studia z Geografii Politycznej i Historycznej, Łódź.

KRUGMAN, P., WELLS, R. (2014), Makroekonomia, Wydawnictwo Naukowe PWN, Warszawa.

KULAK, E. (2016), Kształtowanie się poczucia tożsamości Katalończyków na podstawie piśmiennictwa okresu odrodzenia kulturalnego i narodowego (XIX w.-początek XX w.), TAiWPN Universitas, Kraków.

OYRZANOWSKI, B. (1997), Makroekonomia, Wydawnictwo Profesjonalnej Szkoły Biznesu, Kraków.

SPEARS, I. S. (red.) (2004), States Within States. Incipient Political Entities in the Post-Cold War Era, Palgrave Macmillan US, New York.

SYKULSKI, L. (2014), Geopolityka. Skrypt dla poczatkujacych, Grategia, Częstochowa, Skrypty naukowe - Geopolityka XXI.

TUÑÓN DE LARA, M. (red.) (1982), Historia de España, t. 5: La frustración de un imperio (1476-1714), Labor, Barcelona.

WEBER, M. (2002), Gospodarka i społeczeństwo. Zarys socjologii rozumiejacej, tłum. i wstęp D. Lachowska, Warszawa.

WISZNIOWSKI, R. (2013), Przełomy państwa współczesnego. Przypadek Szkocji i Katalonii, Elipsa, Warszawa. 


\section{Druki ciągłe}

BOYLAN, B. (2015), „In Pursuit of Independence. The Political Economy of Catalonia's Secessionist Movement", Nations and Nationalism, 21(4) s. 761-785, https://doi.org/10.1111/nana.12121.

GOLEMO, K. (2017), „Nowi Katalończycy. Tożsamość i integracja społeczno-kulturowa dzieci imigrantów w Barcelonie”, Pogranicze. Studia Spoteczne, 29, Białystok, s. 123-167, https://doi.org/10.15290/pss.2017.29.06. KALINOWSKI, Ł. (2016), „Prawne aspekty secesji Katalonii”, Internetowy Przegląd Prawniczy TBSP UJ, 3(25), Kraków, s. 182-198.

KOCHANECKI, A. (2018), „Dążenia niepodległościowe Katalonii w XX i XXI w. w kontekście referendum niepodległościowego z 1 października 2017 r.", Przegląd Geopolityczny, 23, Kraków, s. 144-157.

KOSIENKOWSKI, M. (2008), „Quasi-państwo w stosunkach międzynarodowych”, Stosunki Międzynarodowe - International Relations, 38(3-4), Warszawa, s. 151-162.

KUCHCIAK, A. (2017), „Autonomia terytorialna w europejskich krajach śródziemnomorskich" w: Aktualne problemy ochrony wolności i praw mniejszości w Polsce i na świecie, s. 109-122, Prawnicza i Ekonomiczna Biblioteka Cyfrowa. Wydział Prawa, Administracji i Ekonomii Uniwersytetu Wrocławskiego, [on-line] https://www.repozytorium.uni.wroc.pl/ dlibra/publication/94629/edition/89237/content, 26.04.2021.

LESIEWICZ, E. (2020), „Independence Referenda in Catalonia and Their Political Significance", Przeglad Politologiczny, 4, Poznań, s. 73-85, https:// doi.org/10.14746/pp.2020.25.4.5.

OSKAM, J. (2014), „A New State in Europe? Scenarios for Catalan Self-determination", Futures, 64, s. 51-60.

PONS I NOVELL, J., TREMOSA I BALCELLS, R. (2005), „Macroeconomic Effects of Catalan Fiscal Deficit with the Spanish State (2002-2010)", Applied Economics, 37(13), s. 1455-1463, https://doi. org/10.1080/00036840500109134.

SASOR, R. (2015), „Katalońska pamięć historyczna i kryzys hiszpańskiej państwowości. Przyczynek", Studia Iberystyczne, 14(14), Kraków, s. 85107, https://doi.org/10.12797/SI.14.2015.14.06. 
ŚMIGASIEWICZ, M. (2014), „Uwarunkowania geopolityczne państw nieuznawanych - casus Tureckiej Republiki Cypru Północnego", Przegląd Geopolityczny, 9, Kraków, s. 183-199.

WLAŹLAK, K. (2016), ,Prawne aspekty autonomii regionalnej w Hiszpanii”, Przeglad Narodowościowy, 5, Zielona Góra, s. 7-16.

\section{Artykuły prasowe}

CARRERAS, F. (2012), „The Economics of Catalan Independence Don't Add Up", [on-line] https://www.theguardian.com/commentisfree/2012/nov/22/ economics-catalan-independence-dont-add-up, 15.08.2020.

KAZIMIERCZUK, A., BARTKIEWICZ, A., MIKULSKI, J., „Referendum w Katalonii. 90 proc. głosujących opowiedziało się za niepodległością”, 1.10.2017, [on-line] https://www.rp.pl/Polityka/171009995-Referendu$\mathrm{m}$-w-Katalonii-90-proc-glosujacych-opowiedzialo-sie-za-niepodleglosc ia.html, 26.04.2021.

„Kryzys w Katalonii i jego skutki dla gospodarki Hiszpanii”, Rynek Inwestycji (2017), [on-line] http://rynekinwestycji.pl/kryzys-w-katalonii-i-jegoskutki/, 15.04.2021.

„MFW. Niepewność w Katalonii może podważyć zaufanie inwestorów”, Dziennik Gazeta Prawna 6.10.2017, [on-line] https://biznes.gazetaprawna.pl/artykuly/1076265,niepewnosc-w-katalonii-moze-podwazyczaufanie-inwestorow.html, 26.03.2021.

STASIŃSKI, M. (2021), „«Katalonia się zapada». Nacjonaliści kłócą się o zdalnego premiera", 6.04.2021, [on-line] https://wyborcza. pl/7,75399,26952090,katalonia-sie-zapada-nacjonalisci-kloca-sie-ozdalnego-premiera.html, 2.05.2021.

\section{Strony internetowe, slowniki, raporty}

Cargill (2021), [on-line] https://www.cargill.com.pl/, 15.05.2021.

Catalunya.com (2021), „Catalunya Convention Bureau”, [on-line] https:// www.catalunya.com/en/catalunya-convention-bureau-ccb, 22.01.2021.

Eures (2020), „Labour Market Information (Ragion: Cataluña)”, [on-line] https://ec.europa.eu/eures/main.jsp?catId $=443 \& 1 \mathrm{mi}=\mathrm{Y} \&$ acro=lmi\&lang= en\&recordLang $=$ en\&parentId $=\&$ countryId $=E S \&$ regionId $=E S 1 \&$ nuts $2 \mathrm{Co}$ $\mathrm{de}=\mathrm{ES} 11 \&$ nuts 3 Code $=$ null\&mode $=$ text\&regionName $=$ Catalu $\% \mathrm{C} 3 \% \mathrm{~B} 1 \mathrm{a}$, 25.04.2021. 
Eures (2020), „Información sobre el mercado laboral”, [on-line] https://ec.europa.eu/eures/main.jsp?catId=443\&acro=lmi\&lang=es\&countryId=ES\&regionId $=\mathrm{ES} 5 \&$ nuts2Code $=\mathrm{ES} 51 \&$ nuts $3 \mathrm{Code}=$ null\&regionName $=$ Catal $\mathrm{u} \% \mathrm{C} 3 \% \mathrm{~B} 1 \mathrm{a}, 25.04 .2021$.

Eurostat (2019), „EU Population Up to Over 513 Million on 1 January 2019. More Deaths than Births", [on-line] https://ec.europa.eu/eurostat/documents/2995521/9967985/3-10072019-BP-EN.pdf/e152399b-cb9e-4a42a155-c5de6dfe25d1, 20.04.2021.

Eurostat (2020), „Ośrodki turystyczne - liczba noclegów w turystycznych obiektach noclegowych, 2018 r.", [on-line] https://ec.europa.eu/ eurostat/statisticsexplained/index.php?title=Tourism_statistics/pl\&ol$\mathrm{did}=483854$ \#Noclegi_wykupione_przez_nierezydent.C3.B3w_w_UE27:_na_pierwszym_miejscu_Hiszpania, 7.03.2021.

Generalitat de Catalunya (2020), „Catalan Economy. The Strength of An Innovative and Outward-looking Nation", [on-line] http://economia.gencat. cat/web/.content/70_economia_catalana/Subinici/angles/glimpse-catalaneconomy/the-Catalan-economy.pdf, 2.04.2021.

Generalitat de Catalunya (2021), „Catalonia Industry Suppliers”, [on-line] http://suppliers.catalonia.com, 25.04.2021.

Idealista News (2020), „Cudzoziemcy zainwestowali 29 miliardów EUR w hiszpański sektor nieruchomości w ciągu ostatnich czterech lat”, [on-line] https://www.idealista.com/pl/news/nieruchomosci-na-sprzedazhiszpania/2020/01/12/7205-cudzoziemcy-zainwestowali-29-miliardow, 22.04.2021.

Nota de Conjuntura Econòmica (2020), „Anàlisi de l'evolució de l'economia catalana i el seu entorn Informe anual 2019", [on-line] http://economia. gencat.cat/web/.content/70_economia_catalana/arxius/publicacions_periodiques/nota_de_conjuntura/NCE-110/NCE-110.pdf, 28.01.2021.

Pirineus (2021), „La Pica d'Estats”, [on-line] https://www.visitpirineus.com/ en/node/126, 2.05.2021.

Statista (2021), „Annual Number of International Tourist Arrivals in Catalonia 2008-2020", [on-line] https://www.statista.com/statistics/447823/ yearly-number-of-international-tourists-visiting-catalonia/, 28.04.2021.

Statistical Institute of Catalonia (2021), „Comptes econòmics anuals de Catalunya", [on-line] https://www.idescat.cat/pub/?id=piba, 26.04.2021. 
Statistical Institute of Catalonia (2021), ,Foreign Investment. By Activity Branches", [on-line] https://www.idescat.cat/indicadors/?id=anual$\mathrm{s} \& \mathrm{n}=10467 \& \mathrm{col}=1 \&$ lang=en, 27.04.2021.

Statistical Institute of Catalonia (2021), „Industrial Production Index (IPI). By Large Industrial Sectors", [on-line] https://www.idescat.cat/indicador$\mathrm{s} /$ ? id=anuals\& $\mathrm{n}=10504 \&$ lang $=\mathrm{en}, 26.04 .2021$.

Statistical Institute of Catalonia (2021), „Inversió estrangera. Per branques d'activitat", [on-line] https://www.idescat.cat/indicadors/?id=anual$\mathrm{s} \& \mathrm{n}=10467 \& \mathrm{col}=1 \&$ lang=en, 26.04.2021.

Statistical Institute of Catalonia (2020), „Population on 1 January. Provinces", [on-line] https://www.idescat.cat/pub/?id=aec\&n=245\&lang=en, 28.04.2021.

Statistical Institute of Catalonia (2021), „Producte interior brut. Revisió estadística 2019. Oferta", [on-line] https://www.idescat.cat/indicadors/?id=anuals\&n=10438\&col=1, 26.04.2021.

Statistical Institute of Catalonia (2021), „Unemployment Rate. By Sex. Provinces", [on-line] https://www.idescat.cat/pub/?id=aec\&n=318\&lang=en, 26.04.2021.

The Financial Times Ltd (2020), „fDi European Cities and Ragions of the Future 2020/2021 Special Report", [on-line] https://www.fdiintelligence. com/article/76767, 25.01.2021. 